J. Perinat. Med. $16(1988) 417$

\section{Introduction of a programme for intravascular transfusions at severe rhesus isoimmunization}

\author{
Magnus Westgren, Fahad Jabbar, Joergen Falk Larsen, Feryal Rahman, Anders \\ Selbing, and Magnus Stangenberg
}

Department of Obstetrics and Gynaecology, King Faisal Specialist Hospital and Research Centre, Riyadh, Kingdom of Saudi Arabia

\section{Introduction}

Management of severely affected isoimmunized patients has traditionally involved intraperitoneal transfusions if the fetal lungs are immature. However, the outcome of this procedure is doubtful in cases of hydropic fetuses since they seem to have an inadequate absorption of erythrocytes from the peritoneal cavity. More recently, it has been reported that direct intravascular transfusions in utero can improve the outcome for this cathegory of patients. The latter technique was pioneered by RODECK et al [9] using a fetoscopic approach and was later performed in a less combersome way by BANG [1], who performed the transfusion under ultrasonic guidance. Since then, the technique has been introduced in many perinatal units $[2-5,8$, 9, 11]. In Saudi Arabia severe rhesus isoimmunization is still a common perinatal problem and one assumes that approximately $5-10 \%$ of the perinatal mortility is related to blood group incompatibility [7]. The main reason for this is that anti-D prophylaxis has not until recently been widely implemented and that many women experience a high number of pregnancies. Furthermore, many women at risk will not attend standardized antenatal care and will not be recognized until they are in an advanced stage of the disease. Consequently, the isoimmunized patient presents a rather common challange to the obstetrician practicing in this country. The aim of the present investigation was to introduce and evalutate intravascular transfusions in severe cases of rhesus isoimmunization at KING FAISAL SPECIALIST HosPITAL (KFSH) in Riyad.

\section{Patients and methods}

From May, 1986 to May, 1988, 41 patients with severe rhesus isoimmunization and with a gestational age of less than 30 weeks were referred to KFSH. Table I gives detailed information about the patients.

According to the management protocol which was approved by the Ethics and Research Committee of KFSH, all patients were evaluated with fetal blood sampling when entering the programme. In case of fetal anaemia, intravascular transfusions were carried out. These procedures were performed as follows: the mother was sedated with $10 \mathrm{mg}$ of intramuscular morphin and $25 \mathrm{mg}$ of promethazin one hour before the procedure. A 22 gauge preheparinized spinal needle was guided to the cord insertion in the placenta or into the fetal heart with the use of continuous ultrasound monitor (Philips SDR 1500 sector scanner). According to the protocol, cardiac transfusion should be carried out when it was impossible to perform the transfusion into the cord. However, during the study period, with the introduction of new members in the transfusion team, there was a tendency to drift away from the original policy and during the last year of the study, the cardiac approach was the first choice in many cases.

A detailed description of the technique of intracardiac transfusion has recently been published [13]. After insertion of the needle, $3.0-4 \mathrm{ml}$ of fetal blood was drawn for analyis of haematological indices (CoulTER Counter 5 plus 3), acid-base balance (Coning $178 \mathrm{pH}$ blood gas analyzer) and 
Table I. Description of the rhesus isoimmininzed patients.

Past obstetrical history:

Number of stillbirths due to $\mathrm{Rh}$

No. of patients

13

14

7

7

$>7$

Preprocedure haemoglobin at the first fetal blood sampling

No. of patients

$$
<30 \mathrm{~g} / 1
$$

$30-50 \mathrm{~g} / 1$

$51-70 \mathrm{~g} / 1$

$71-90 \mathrm{~g} / 1$

$>90 \mathrm{~g} / 1$

Ultrasound appearance at admission

\begin{tabular}{lr}
\hline Normal & 25 \\
Hydrops & 13 \\
Terminal hydrops* & 3
\end{tabular}

* ascites, pleura and pericardial effusion, subcutanous oedma, lack of fetal movements and spontanous bradychardia

KLEIHAUER-BETHKe test. The transfusion volume was calculated according to the method described by RoDECK et al [10] and the aim was to raise the haematocrit to $30 \%$. However, at intracardiac transfusions, due to fear of central overload and technical difficulties to keep the needle in the correct position for a longer period, considerably smaller blood volumes $(5-35 \mathrm{ml})$ were administered. Type $0, \mathrm{Rh}$ negative, CMV antibody negative packed red cells were administered at a rate of about $1 \mathrm{ml}$ per minute. After the transfusion, a post procedure sample was obtained for evaluation of haemoglobin and acid base balance. Immediately after the transfusion the fetal heart was scanned for 15 minutes and the patient was later monitored with cardiotochogram for another hour. Subsequent transfusions were carried out at $3-15$ days interval depending on the severity of the anaemia and the ultrasonic appearance of the fetus. In non-hydropic fetuses, the haematocrit drop was assumed to be one point per day as reported by RODECK et al [10] while in more severe cases, according to our experience, the drop is usually faster.

Later fetal surveillance included weekly ultrasound examinations and non stress tests. The aim in each case was to enable the mother to carry her pregnancy until at least the 31 st week of gestation. All patients were delivered at the KFSH and all surviving infants were treated at the neonatal intensive care unit of this hospital. Autopsy was only permitted in two of the stillbirths.

\section{Results}

During the study period, 37 patients underwent a total of 92 intravascular transfusions. Of these, 77 were intracardiac, 13 umbilical vein and two umbilical artery transfusions. Fetal blood sampling without any transfusions were carried out 27 times in these and the remaining four patients.

Table II presents the distribution of invasive fetal procedures in relation to gestational age. Umbilical transfusions were predominately performed in fetuses with a gestational age of more than 25 weeks. Procedure related complications occurred at eight $(10 \%)$ intracardiac and two $(13 \%)$ umbilical transfusions.

The complications and the consequences for the fetus are presented in table III. In three patients, increased amount of fluid in the pericardial space could be observed immediately after the procedure, suggesting haemopericardium. In one of these cases it was possible to aspirate the blood (previously described in detail [13]) while the other two exspired soon after the transfusion. Post-mortem examinations were performed revealing car- 
Table II. Invasive fetal procedures in relation to gestational age (procedure related complications in brackets).

\begin{tabular}{lllllll}
\hline & \multicolumn{6}{l}{ Gestational age (weeks): } \\
\cline { 2 - 6 } & $18-20$ & $21-22$ & $23-24$ & $25-26$ & $27-28$ & $29-30$ \\
\hline Intravascular transfusions: & 4 & 6 & $15(3)$ & $19(2)$ & $17(2)$ & $16(1)$ \\
- cardiac & - & - & - & $3(1)$ & 2 & $8(1)$ \\
- umbilical vein & - & - & - & & 1 & 1 \\
- umbilical artery & & & & & & 3 \\
Fetal blood sampling: & 2 & 8 & 3 & 5 & 1 & 4 \\
- cardiac & - & - & - & 1 & & \\
- umbilica vein & & & & & &
\end{tabular}

Table III. Complications at intravascular transfusions and consequences for the fetus.

\begin{tabular}{|c|c|c|}
\hline & Complications & Outcome \\
\hline Patient 1: & $\begin{array}{l}\text { Fetal heart arrest at three consecutive intracardiac transfusions at } 21,23 \\
\text { and } 24 \text { weeks. After transfusion into the cord in the } 26 \text { th week, bleeding } \\
\text { from puncture site }\end{array}$ & $\begin{array}{l}\text { Stillborn } \\
\text { 26th week }\end{array}$ \\
\hline Patient 2: & $\begin{array}{l}\text { Haemopericardium at } 3 \mathrm{rd} \text { intracardiac transfusion, } 7 \mathrm{ml} \text { blood was aspi- } \\
\text { rated. Delivered electivly } 3 \text { weeks later }\end{array}$ & $\begin{array}{l}\text { C.S. 32nd week } \\
\text { alive and well }\end{array}$ \\
\hline Patient 3: & $\begin{array}{l}\text { Fetal tachycardia after cord transfusion at } 29 \text { th week. Blood stained } \\
\text { amniotic fluid }\end{array}$ & $\begin{array}{l}\text { Emergency C.S. } \\
\text { alive and well }\end{array}$ \\
\hline Patient 4: & Haemopericardium at the 6th intracardiac transfusion 30 weeks & $\begin{array}{l}\text { Stillborn. } \\
\text { Autopsy: } 0 \text { neg } \\
\text { blood clot in } \\
\text { pericardial } \\
\text { space }\end{array}$ \\
\hline Patient 5: & Haemopericardium at 1 st transfusion 26 weeks & $\begin{array}{l}\text { Stillborn. } \\
\text { Autopsy: } 0 \text { neg } \\
\text { blood clot in } \\
\text { pericardial } \\
\text { space }\end{array}$ \\
\hline Patient 6: & $\begin{array}{l}\text { Fetal heart arrest of unknown cause } 4 \mathrm{hrs} \text { after intracardiac transfusion } \\
\text { in the 26th week }\end{array}$ & Stillborn \\
\hline Patient 7: & $\begin{array}{l}\text { Fetal heart arrest of unknown cause } 4-6 \text { hrs after cord transfusion in } \\
\text { the } 27 \text { th week }\end{array}$ & Stillborn \\
\hline
\end{tabular}

diac tamponade. The clots in the pericardial space consisted of sero-negative blood which, at least, in one of the patients who had received a first transfusion, indicated that the transfusion had been wrongly administered into the pericardial space. The other fetus with sero-negative blood clot in the pericardium, had received its seventh transfusion and it cannot be established if the cardiac tamponade was due to an incorrectly placed needle or bleeding from the heart after the procedure. Two patients with cord transfusions had signs of fetal bleeding from the puncture site immediatly after the transfusion. It was possible to deliver one of these patients (due to fetal tachycardia) with emergency ceasarean section. The other which was a case of fetal trombocytopenia died the next day when it was found to be severely anaemic. In one case of intracardiac and in another of umbilical vein transfusion, the fetus died within six hours after "technically uncomplicated" 
transfusions. Since none of these cases were severely affected (preprocedure haemoglobin 47 and $52 \mathrm{~g} / 1$ respectively), we assumed that the cause of death in these cases is related to the procedure.

Reversal of hydrops could be observed in 10 of 16 patients, three of whom were at a terminal stage of the disease when they were transferred to our unit. Two of these fetuses died soon after an "uncomplicated transfusion".

One transfused fetus developed severe respiratory distress syndrome soon after birth in the 31st week of gestation and died. Thus, the perinatal mortality among transfused fetuses is $8 / 37(21 \%)$ and in the total material $8 / 41(19 \%)$. Another 15 of 33 transfused infants developed moderate to severe respiratory distress syndrom requiring assistant ventilation during the neonatal period. Neonatal exchange transfusions due to hyperbilirubinemia were performed in 18/33 surviving infants. Ten neonates required only one exchange transfusion, six required three and two required five exchange transfusions.

\section{Discussion}

Intrauterine, intravascular transfusion represents the most recent mode of treatment for severe rhesus isoimmunization. In the present patient population where all belonged to WHITFIELD's group D (at least one isoimmunized related death) [14], the perinatal mortality was $21 \%$. These results are slightly poorer than the results reported by other units working with intravascular transfusions but is better than those reported on conventional intraperitoneal transfusions [6]. This applies especially to fetuses with hydrops fetalis while the value of intravascular transfusions in cases of non-hydropic fetuses remains to be established.

What distinguishes this study from previous studies is the use of intracardiac fetal transfusions. The reason for this approach was the difficulties in performing conventional chordocentesis with the ultrasound equipment available. The results suggest that this approach is problematic and is afflicted with several potentially dangerous complications. When blood is given directly into the heart, the blood with high packed cell volume and low $\mathrm{pH}$ may enter the coronary circulation which may lead to arythmias and asystole. Furthermore, if the surgeon is not perfectly aware of the position of the needle tip, the blood can easily be administered into the pericardial space. After removal of the needle, bleeding from the puncture site may lead to haemipericardium and subsequent cardiac tamponade. All these complications occurred in the present study and they clearly illustrate the potential danger of the procedure. Although complications also occur at cord transfusions, the severity of the complications at intracardiac transfusions made us try to limit the use of this method as much as possible. After being equipped with up to date ultrasound units we are therefore at the present time moving from cardio- to chordocentesis. However, in the most immature cases, we still feel that this method has a place and it should be emphasized that no complications occurred at simple fetal blood samplings.

Another fact that should be commented upon when discussing complications at invasive fetal procedures is the training of the transfusion team. Five of six complications which led to fetal death in the present study were caused by members of the team who were in the process of learning. When they later gained experience, the results improved. Thus, although needling of the fetus is well within the grasp of any capable obstetrical ultrasonographer, training must be under close supervision and the operator has to perform a certain amount of procedures to gain sufficient experience, thereby maximizing safety. Thus, perinatal care of severely $\mathrm{Rh}$ affected fetuses cannot be acomplished in every hospital but should be regionalized to a few institutions with an experienced staff and where necessary equipment is available.

A group of patients who obviously benefits from intravascular transfusions are those with an early onset of hydrops. In the present study, resolution of hydrops was observed in 9/16 hydropic fetuses. Similar results have been reported by others [5, 12]. In cases of so called terminal hydrops where the fetus is at the end stage of the disease, most cases are not salvagable. When calculating the blood volume by haemoglobin haemodilution technique, our results indicate that these fetuses are hypervolaemic and we have therefore treated them with frequent small top-up transfusions. By this method it was possible to save one infant with initial haemoglobin concentration of $20 \%$ of its normal value. We speculate that larger blood volumes or exchange transfusions will lead to circulatory overload in these cases.

Finally, intrauterine, intravascular transfusion is a valuable method in the management of severly 
isoimmunized fetuses. Problems concerning technique and indications remain to be solved. So fár, there has been a paradoxal situation since this service has been available in advanced centres in countries where rhesus isoimmunization is quite a rare problem. It is a challenging task in the future to provide this mode of management also in countries where experience in fetal diagnosis and treatment is rather limited but where rhesus isoimmunization is still a major perinatal problem.

\begin{abstract}
Thirtyseven fetuses with severe rhesus isoimmunization with a gestational age of less than 30 week underwent 92 intravascular transfusions. Of these, 77 were intracardiac, 13 umbilical vein and two umbilical artery transfusions. Procedure related complications ocurred at eight $(10 \%)$ intracardiac and at two $(14 \%)$ umbilical cord
\end{abstract}

transfusions. Reversal of hydrops was observed in 10 of 16 fetuses. The perinatal mortality among transfusion treated fetuses was $8 / 37(21 \%)$. It is concluded that intravascular, intrauterine transfusion leads to improved results among fetuses with early onset of hydrops. Problems concerning indications and technique are discussed.

Keywords: Fetal therapy, prenatal diagnosis, $\mathrm{Rh}$ isoimmunization.

\section{Zusammenfassung}

Einführung eines Programms zur Therapie bei schwerer Rhesus-Isoimmunisierung durch intravaskuläre Transfusionen

In einem Zeitraum von zwei Jahren wurden 41 Patienten mit schwerer Rhesus-Isoimmunisierung und einem Gestationsalter unter 30 Wochen mit insgesamt 92 fetalen intravaskulären Transfusionen behandelt bzw. punktiert. Davon erfolgten 77 intracardial, 13 in die Nabelvene und 2 in die Nabelarterie. Zusätzlich wurden 27 fetale Blutproben entnommen. Bei den intracardialen Transfusionen traten in 8 Fällen Komplikationen auf (10\%), bei den Transfusionen in die Nabelschnur in 2 Fällen $(14 \%)$. Diese Komplikationen werden detailliert beschrieben. Die perinatale Mortalität im Gesamtkollektiv betrug 19\% (8 von 41 Feten), die bei dem mit intravas- kulären Transfusionen behandelten Kollektiv 21\% (8 von 37 Feten). Bei 10 von 16 Feten wurde ein Rückgang des Hydrops verzeichnet. Wir meinen, daß intrauterine, intravaskuläre Transfusionen bei Feten mit früher Ausbildung eines Hydrops echte Erfolge bringen können. Bei nicht-hydropischen Feten muß der therapeutische Wert von intravaskulären Transfusionen noch genauer untersucht werden. Hierzu sind prospektive, randomisierte Studien notwendig, in denen das konventionelle Verfahren mittels intraperitonealer Transfusionen den neuen Techniken gegenübergestellt wird. Probleme im Hinblick auf Indikation, Zeitpunkt und technische Einzelheiten bei intravaskulären Transfusionen werden diskutiert.

Schlüsselwörter: Fetaltherapie, pränatale Diagnose, Rhesus-Isoimmunisierung.

\section{Résumé}

Introduction d'un programme de transfusion intra-vasculaire lors des iso-immunisations rhésus graves

On a traité par 92 transfusions fotales intra-vasculaires 41 patientes présentant une iso-immunisation rhésus grave et un âge gestationnel inférieur à 30 semaines, sur une période de deux ans. Parmi ces transfusions 77 ont été réalisées en intra-cardiaques, 13 dans la veine ombilical et 2 dans l'artère ombilicale. En outre, 27 prèlèvements de sang fœtal ont été effectués. Il y a eu des complications liées à la technique au cours de 8 transfusions intra-cardiaques $(10 \%)$ et de 2 transfusions au niveau du cordon ombilical (14\%). Ces complications sont décrites en détail.
La mortalité périnatale de l'ensemble a été de 8 su 41 $(\mathbf{1 9 \%})$ et chez le patientes traitées par transfusion intravasculaires de 8 sur $37(21 \%)$.

La disparition de l'hydrops a été observée chez 10 des 16 fœtus. On en conclue que les transfusions in utéro intra-vasculaires améliorent les résultats chez les fœtus avec hydrops d'apparition précoce. Pour les cas sans hydrops la valeur des transfusions intra-vasculaires doit être plus vérifiée et il y a besoin d'études radomisées prospectives afin de comparer cette technique avec les transfusions intra-péritonéales conventionnelles.

Les auteurs discutent les problèmes concernant les indications, la programmation et la technique en rapport avec les transfusions intra-vasculaire.

Mots-clés: Diagnostic prénatal, incompatibilité thésus, thérapeutique fœtale. 


\section{References}

[1] BANG J, JE Bock, Trolle D: Ultrasound-guided fetal intravenous transfusion for severe hemolytic disease. Br Med J 284 (1982) 373

[2] Berkowitz RL, U Chitkara, JD Goldberg, J WILKINS, FA CHERVENAK, L LYNCH: Intrauterine intravascular transfusions for severe red blood cell isoimmunization, ultrasound-guided approach. Am J Obstet Gynecol 155 (1986) 574

[3] De CRispigny LC, HP Robinson, M Quninn, L Doyle, A Ross, M CAUCHI: Ultrasound-guided fetal blood transfusion for severe rhesus isoimmunization. Obstet Gynecol 66 (1985) 525

[4] Grannum PA, JA Capel, SC Plaxe, Al Scioscia, JC HoBBINS: In utero exchange transfusion by direct intravascular injection in severe erythroblastosis fetalis. N Engl J Med 314 (1986) 1431

[5] Grannum PA, JA Copel, FR Moya, AL Sciosa, JA ROBERT, HN WinN, BC COSTER, CB BURDINE, JC HobBins: The reversal of hydrops fetalis by intravascular intrauterine transfusion in severe isoimmune fetal anemia. Am J Obstet Gynecol 158 (1988) 914

[6] HaRman CR, FA Manning, JM Bowman: Severe $\mathrm{Rh}$ diseases - poor outcome is not inevitable. Am J Gynecol 145 (1983) 823

[7] Olhusson A: Better perinatal care in Saudi Arabia. Ann Saudi Med 3 (1985) 169

[8] Pollock JM, JM Bowman, FA Manning, CR HARMAN: Fetal blood sampling in Rh hemolytic disease. Vox Sang 53 (1987) 139

[9] Rodeck CH, JR Kemp, CA Holman, DN WhitMORE, J KARNICKI, MA AUSING: Direct intravascular fetal blood transfusion by fetoscopy in severe rhesus isoimmunization. Lancet 1 (1981) 625
[10] Rodeck CH, KH Nicolaides, S Warsof: The management of severe rhesus isoimmunization by fetoscopic intravascular transfusions. Am J Obstet Gynecol 150 (1984) 769

[11] SEEDS JW, WA Bowes: Ultrasound-guided fetal intravascular transfusion in severe rhesus isoimmunization. Am J Obstet Gynecol 154 (1986) 1105

[12] Socol ML, SN Macgregor, BW Pielet, RK TAMURA, RE SABBAGHA: Percutanous umbilical transfusion in severe rhesus isoimmunization. Resolution of fetal hydrops. Am J Obstet Gynecol 157 (1987) 1369

[13] Westgren M, A Selbing, M Stangenberg: Fetal intracardiac transfusion in patients with severe rhesus isoimmunization. Br J Med 296 (1988) 885

[14] WhITFIELD CR: A three-year assessment of an action line method of timing intervention in rhesus isoimmunization. Am J Obstet Gynecol 108 (1970) 1239

Received August 13, 1988. Revised September 12, 1988. Accepted September 22, 1988.

Magnus Westgren, $\mathrm{MD}, \mathrm{PhD}$

Karolinska Institutet

Department of Obstetrics

and Gynaecology

Danderyd Hospital

S-182 88 Danderyd

Sweden 